\title{
New record of Podilymbus podiceps (Linnaeus, 1758) (Podicipediformes, Podicipedidae) in the Patagonian region of southern Chile
}

\author{
Javier Godoy-Güinao, ${ }^{1,2}$ Juan Carlos Llancabure, ${ }^{1}$ Iván A. Díaz ${ }^{1,2}$ \\ 1 Laboratorio de Biodiversidad y Ecología del Dosel, Instituto de Conservación, Biodiversidad y Territorio de la Universidad Austral de Chile, \\ Casilla 567, Valdivia, Chile. 2 Fundación Mar Adentro, Av. El Golf 99 of. 901, Santiago Chile. \\ Corresponding author: Javier Godoy-Güinao, jagodoyg@gmail.com
}

\begin{abstract}
We report a new record of Podilymbus podiceps (Linnaeus, 1758) in the southern Chilean Patagonia, $120 \mathrm{~km}$ south of previous records on the western side of the Andes, and more than $400 \mathrm{~km}$ south of their known distribution area on the eastern side of the Andes. This is the southernmost record of this species in Chile and one of the southernmost records worldwide, highlighting the vagrancy of this species in southern Patagonia.
\end{abstract}

\section{Key words}

Vagrancy; Chilean Patagonia; Grebes; General Carrera Lake; Puerto Ingeniero Ibáñez.

Academic editor: Caio J. Carlos | Received 13 May 2017 | Accepted 21 February 2018 | Published 9 March 2018

Citation: Godoy-Güinao J, Llancabure JC, Díaz IA (2018) New record of Podilymbus podiceps (Linnaeus, 1758) (Podicipediformes, Podicipedidae) in the Patagonian region of southern Chile. Check List 14 (2): 309-312. https://doi.org/10.15560/14.2.309

\section{Introduction}

Podilymbus podiceps (Linnaeus, 1758) is an aquatic bird species that is widely distributed across North and South America (Llimona et al. 1992). The southern cone of South America is inhabited by the subspecies $P$. podiceps antarcticus (Lesson, 1842) (Llimona et al. 1992, Clements et al. 2015), which is distributed from Venezuela to southern Argentina and Chile, where it inhabits lakes, lagoons, and rivers (Jaramillo et al. 2005). P. podiceps is commonly observed alone or in pairs, but never in flocks (Goodall et al. 1951).

$P$. podiceps is considered the rarest species of grebe in the Chile (Goodall et al. 1951), it has no declared conservation status in this country (Chilean Environmental Ministry 2017), and globally has been classified as Least Concern by Birdlife International (2016).
Throughout the southern part of its distribution range, $P$. podiceps is distributed differently on either side of the Patagonian Andes (Birdlife International 2016). In Chile, it is known from the Coquimbo Region $\left(30^{\circ} \mathrm{S}\right)$ south to Pumalin Park ( $\left.42^{\circ} \mathrm{S}\right)$ in continental Chile, and to Chonchi $\left(43^{\circ} \mathrm{S}\right)$ on the Chiloé Archipelago (Goodall et al. 1951, Jaramillo et al. 2005). On the eastern side of the Andes, $P$. podiceps inhabits much of South America, south to $42^{\circ} \mathrm{S}$, where the extensive steppes of the Chilean and Argentine Patagonia begin (Goodall et al. 1951, Birdlife International 2016). This species may be a vagrant throughout Patagonia, as indicated by sporadic sightings from south of $42^{\circ} \mathrm{S}$. For instance, 1 individual was observed $300 \mathrm{~km}$ south of the Chiloé Archipelago, near Quitralco stream $\left(45^{\circ} 36^{\prime} \mathrm{S}, 073^{\circ} 15^{\prime} \mathrm{W}\right)$, between fjords and channels on the western side of the Andes (Birdlife International 2016). In the Argentine Patagonia, occasional records between 


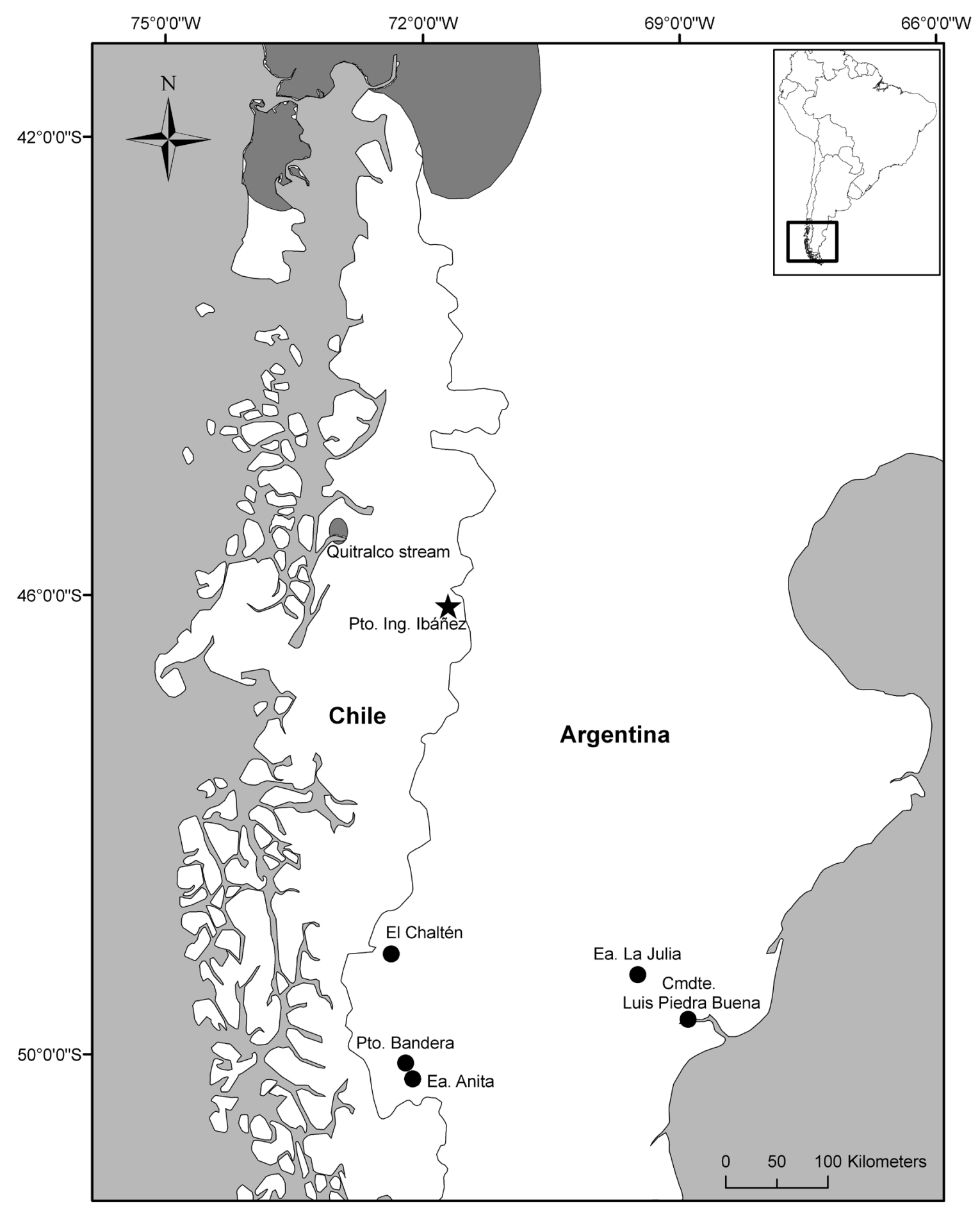

Figure 1. Distribution of Podilymbus podiceps (dark gray) in southern Chile and Argentina according to Birdlife International (2016). Location of vagrant $P$. podiceps recorded in Puerto Ingeniero Ibáñez, southern Chile (star) and southern Argentina (points). In Chile: Pto. Ing. Ibáñez (2015). In Argentina: El Chaltén, Pto. Bandera and Estancia (Ea) Anita (2005), Cmdte. Luis Piedra Buena (2004 and 2008), Estancia (Ea) La Julia (2017).

$49^{\circ}$ and $50^{\circ} \mathrm{S}$ (Darrieu et al. 2008, checklists S34463672 and $\mathrm{S} 35345575$ on eBird, Imberti pers. comm.) have also been reported (Fig. 1). Here, we report the southernmost vagrant record of this species in Chile.

\section{Methods}

Our new sighting of $P$. podiceps took place on the eastern side of the Andes mountain range in southern Chile, within the framework of a permanent bird monitoring program in Puerto Ingeniero Ibáñez, conducted from 2013 to the present (Godoy-Güinao et al. unpublished data). The datum used to record the geographic coordinates of our new record is WGS84.

\section{Results}

New record. On July 23, 2015, JG and JL observed and photographed 1 individual of $P$. podiceps on the north shore of General Carrera Lake, Puerto Ibáñez, Aysén 


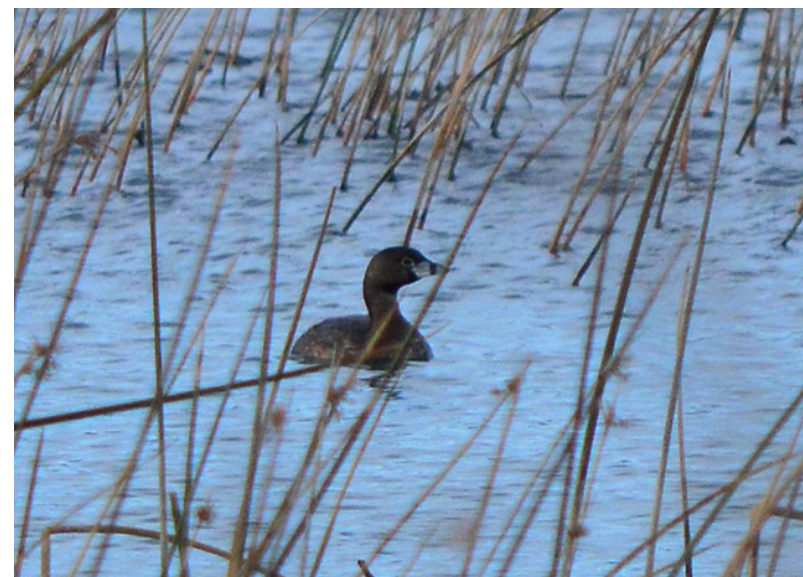

Figure 2. Podilymbus podiceps individual recorded at the General Carrera Lake in Puerto Ingeniero Ibáñez, southern Chile on 23 July 2015. Photograph by JL.

region, southern Chile $\left(46^{\circ} 17^{\prime} \mathrm{S}, 071^{\circ} 56^{\prime} \mathrm{W}, 212 \mathrm{~m}\right.$ elev., Fig. 2).

Identification. The photographed individual had light gray plumage on its body, with dark gray marks on its back. Its beak was short, broad, and whitish, crossed by a thick, vertical black line. Its brown eyes had white periophthalmic rings, and its chin was black (Fig. 2). There was no tuft on its head (Fig. 2). These features are characteristic of $P$. podiceps and distinguish it from other grebe species in Chile, which have characteristics such as white cheeks, crests, and colorful eyes (Goodall et al. 1951, Jaramillo et al. 2005).

\section{Discussion}

This new record is $120 \mathrm{~km}$ southeast of the nearest vagrant records in the Aysén region and more than 400 $\mathrm{km}$ south of the known distribution areas of $P$. podiceps on the eastern side of the Andes (Fig. 1). We believe that this record is the southernmost in Chile (Fig. 1).

Podilymbus podiceps is a widely distributed bird species across North and South America (Llimona et al. 1992, Clements et al. 2005), and it has been recorded outside of its normal distribution, such as in France, Grenada, Guadeloupe, Iceland, Ireland, the Netherlands, Norway, Poland, Portugal, Spain (Canary Islands), and the United Kingdom (Birdlife International 2016). The records from southern Argentina (Darrieu et al. 2008, checklists S34463672 and S35345575 on eBird, Imberti pers. comm.) also represent vagrant observations of this species (Fig. 1). The lack of previous records of this species from other Chilean Patagonian lakes (Goodall et al. 1951, Jaramillo et al. 2005, Couve et al. 2016) and during the previous 2 years (summer and winter) of bird monitoring on this lake suggests that our sighting is most likely related to vagrancy rather than pseudo-vagrancy (Dias et al. 2010, 2014).

According to Dias et al. (2010), vagrancy can be explained by demographic dispersion, a search for resources, or disorientation. The global population of $P$. podiceps presents a stable trend, without extreme fluctuations and not increasing (Birdlife International 2016). Therefore, our finding may not be related to demographic expansion and dispersion of $P$. podiceps population; if it were, we should have recorded a permanent establishment and an increasing population in General Carrera Lake. On the other hand, a search for resources could explain the presence of this species in General Carrera Lake. However, without population monitoring it is difficult to identify their foraging behavior and know the details of their search for resources. Finally, the year of our record coincides with the very strong ENSO (El Niño-Southern Oscilation) during 2015-2016, with several frontal systems that caused abundant precipitation in southern Chile (Dirección Meteorológica de Chile 2016). ENSO could influence vagrant behavior (Veit 2000) and explain the presence of $P$. podiceps at General Carrera Lake in the year 2015. However, in southern Argentina, this species was recorded outside its normal distribution range several times before and after our record (Fig. 1).

Long-term and large-scale monitoring is necessary to determine the presence of this species in other Patagonian lakes and the possibility of an expansion of its southern distribution. Moreover, permanent monitoring, population studies (Veit 2000), and permanent weather monitoring (Montalti et al. 1999) could provide explanations as to how individuals can end up $1000 \mathrm{~km}$ away from their normal distribution.

\section{Acknowledgements}

We are grateful to Armando Godoy and Olga Güinao for providing logistical facilities in Puerto Ingeniero Ibáñez and Fernando Godoy for his field support. We also thank Santiago Imberti for providing us with relevant information. We thank Christine Harrower for her valuable comments on the manuscript.

\section{Author contributions}

JG conducted the bird censuses and drafted the manuscript; JL participated in the field surveys, photographed the species, and collaborated in the writing of the manuscript; ID provided valuable comments to improve the manuscript, and collaborated in writing and editing the final text.

\section{References}

BirdLife International (2016) Podilymbus podiceps. The IUCN Red List of Threatened Species 2016: e.T22696574A93571798. https://doi. org/10.2305/iucn.uk.2016-3.rlts.t22696574a93571798. Accessed on: 2017-8-24.

Chilean Environmental Ministry (2017) Clasificación de especies del $13^{\circ}$ proceso. http://www.mma.gob.cl/clasificacionespecies/ decimo-tercer-proceso.htm. Accessed on: 2017-9-5.

Clements JF, Schulenberg TS, Iliff MJ, Roberson D, Fredericks TA, Sullivan BL, Wood CL (2015) The eBird/Clements checklist of birds of the world: v2015. http://www.birds.cornell.edu/clementschecklist/download/. Accessed on: 2016-5-19. 
Couve E, Vidal C, Ruiz J (2016) Aves de Chile, sus islas oceánicas y península Antártica. $1^{\circ}$ Edición. Far South Expeditions, Punta Arenas, Chile, 550 pp.

Darrieu C, Camperi A, Imberti S (2008) Avifauna (non Passeriformes) of Santa Cruz province, Patagonia (Argentina): annotated list of species. Revista del Museo Argentino de Ciencias Naturales (nueva serie) 10 (1): 111-145.

Llimona F., del Hoyo J, Bonan A (1992) Grebes (Podicipedidae). In del Hoyo J, Elliot A, Sargatal J (Eds) Handbook of the Birds of the World, Vol. 1. Lynx Edicions, Barcelona, 174-196 pp.

Dias RA, Cardozo JB (2014) First record of the Puna Flamingo Phoenicoparrus jamesi (Sclater, 1886) (Aves: Phoenicopteridae) for the Atlantic coast of South America. Check List 10 (5): 1150-1151. https://doi.org/10.15560/10.5.1150

Dias RA, Gianuca A, Vizentin-Bugoni J, Coimbra MAA (2010) New documented records for two bird species in southernmost Brazil, including the first mention of Agriornis murinus for the country and comments on vagrancy. Revista Brasileira de Ornitologia-Brazilian Journal of Ornithology 18 (40): 7.

Dirección Meteorológica de Chile (2016) Resumen climático 2015 y perspectivas verano EFM 2016. Dirección General de Aeronáutica Civil, Sección Climatología, Santiago, 5 pp.

Goodall JD, Johnson AW, Philippi RA (1951) Las aves de Chile: su conocimiento y sus costumbres. Vol. 2. Platt Establecimientos Gráficos, Buenos Aires, 445 pp.

Jaramillo A, Burke P, Beadle D (2005) Aves de Chile. Lynx Ediciones, Barcelona, $240 \mathrm{pp}$.

Montalti D, Orgeira JL, Di Martino S (1999) New records of vagrant birds in the South Atlantic and in the Antarctic. Polish Polar Research 20 (4): 347-354.

Veit RR (2000) Vagrants as the expanding fringe of a growing population. The Auk 117 (1): 242-245. 